\title{
CERAMICS, CULTURAL CONTINUITY AND SOCIAL CHANGE
}

After the conquest the indigenous ceramic culture persisted. This did not mean that it remained static however; rather it developed and transformed in response to new circumstances. Pre-Hispanic ceramicmaking in central Mexico had few changes during the early colonial period. Clay recipes, method of forming and firing technology were maintained as in earlier times. Shape, surface finishing and decoration of vessels had modifications but objects were still visually associated to the pre-Hispanic tradition (with the exception of the lead glazed wares). The most common Late Aztec ceramics continued to be made after the conquest, although we can recognize that the preferences of potters and users of the vessels began to be modified. For example, the typical Black-on-Orange wares were still produced after 1521, but they became less popular and were no longer made by the end of the early colonial period. Red Wares, in contrast, flourished after the conquest. They became the favorite indigenous-style wares in early colonial times and manifested great creativity.

After 1650 ceramic-making experienced more changes. Clay recipes, method of forming and firing technology were still as in ancient times, but morphology, finishing and decoration were so modified that vessels became gradually more differentiated from their pre-Hispanic antecedents. This trend continues until the present-day. Thus, today vessels do not look as in the pre-colonial past. In central Mexico the majority of the production is now concentrated on lead glazed wares, which are embellished with motifs not related to ancient decorations. The shapes still have resemblance to ancient forms although potters have made many innovations in minor formal details. Nevertheless, the method of forming has been maintained as in the past. In my opinion, this is intimately related to the core of this tradition, and therefore they are signs of the continuation of the pre-Hispanic ceramic culture till the present time.

The method of forming can be considered at the center of a pottery tradition because it is closely associated, and even determines, other 
stages of the process of manufacture such as the clay recipes used, the method of firing, the finishing of the surface and the possible repertoire of vessel shapes. It is also related to a particular scale and schedule of production and work division. That is, it is also connected with the organization of production. This aspect is also at the center of a pottery tradition as the form in which this industry functions (family workshops, factories, cooperatives) determines the manner of knowledge transmission across generations, and therefore the dynamics of ceramic change.

When we observe the ceramic industry in a long-term perspective, that is from 1521 to the present time, we recognize that potters have been more resistant to change in those parts of the pottery process that are closer to the core of the tradition. At one extreme of this process we can locate the decoration of vessels. Artisans have been very open and flexible in this activity. For example, in the first colonial years potters learnt the lead glazing technique to decorate vessels, and it was rapidly and widely extended in central Mexico. Also indigenous-style ceramics that continued to be made after the conquestsuch as the Red Wares, the Black-on-Orange wares and the polchromes-incorporated new decorative elements. Some of them were clearly influenced by the new colonial world, like the vessels' supports in the form of lion claws, the vasijas de negritos represented in the Códice de los Alfareros de Cuauhtitlan, or the painted patterns on Red Wares imitating decorations in Majolica wares. However, other new decorative elements were created out of the pre-Hispanic tradition, such as the great variety of differential polishing for embellishing Red Wares. At the present-day potters continue to be open and creative in vessels' decoration. Although the ornamentation of vessels is usually hastily done and insignificant, artisans are willing to incorporate new motifs or new decorative methods when customers require it.

At the other extreme of the process of production we can locate the method for forming vessels. Artisans have been very conservative in this activity. After the conquest vessels continued to be made with molds as in the past, even after the Spaniards introduced a new method of forming in the early colonial period. The potter's wheel did permit them to make small vessels faster than with molds but this technique did not represent an advantage for native potters. At present vessels continue to be manufactured with molds, even when some potters in some towns also know how to form vessels with the wheel and are skilful in its use. The method of forming consists of a series of motor 
abilities learnt and internalized by potters, often in childhood, that have been made habit, and for this reason, it is difficult to change. The method of forming is also directly related to the potters' own conceptualization about ceramic-making. For example, central Mexican potters visualize vessels as part of a sphere, composed of several horizontal parts in which the neck or rim is the last section to be manufactured. The ideas about how vessels should be made also constitute a habit, and therefore they are difficult to change. However, the permanence of the method of forming is not only due to the fact that motor habits and ideas are difficult to change.

The method of forming used by central Mexican potters is also intimately related to their clay recipes, their methods of firing, and their vessel shapes. That is, the ancient recipe in which clay is blended with sandier clay gives stability to the vessels during drying and firing. This recipe is, however, not practical when vessels are made with the wheel because the presence of large particles in the clay scrapes potter's hands and does not permit them to adequately model the vessels. The vessel shapes distinctive of the Mesoamerican tradition, such as ollas with round bases and globular bodies, bowls with flat bases and angular silhouettes or comales, can be adequately made with molds but not with the wheel. In the case of these kinds of vessels, the permanence of a particular shape is not only a matter of aesthetic but also of function. The form of these vessels is optimal for cooking directly on the hearth, which is the traditional Mesoamerican method of cooking. Also the form of ollas is optimal for cooking beans and maize, as their globular and close shapes maintain moisture for a longer time, and these are traditional Mesoamerican foods. Thus, the method of forming vessels has been preserved as in the pre-Hispanic past because it is intimately related to other elements of indigenous culture that have persisted.

In addition, the method of forming has been kept stable because the knowledge and experience required has been transmitted in the family across generations. According to the artisans, one who can form vessels is viewed as a potter. Members of the family who help in decorating vessels, filling the kilns or mixing the clay are not viewed as potters. In family workshops the knowledge necessary to become a potter, that is, the skills for forming vessels, is as a rule learnt from the parents or older relatives. As a form of respect to them and to the family, this knowledge is maintained and transmitted to younger generations. Also, forming vessels with molds implies a particular dynamic in the workshop. As a rule, potters cannot work alone because the 
quantity of available molds, the various stages of forming and drying the vessels' sections, the space in the workshop and the number of vessels planned to be made require at least two well-coordinated persons. Thus, a drastic change in the method of forming, for example from the use of molds to the use of the wheel, may imply important changes in the organization and schedule of the workshop, and in some families this may also imply changes in other daily activities. That is, the method of forming vessels is at the heart of the ceramic tradition because it is closely connected with several essential aspects of family life, like respect to the elders, cooking habits and domestic organization.

Between decoration and method of forming we can recognize other parts of the process of manufacture that may be modified if they represent a benefit for potters and if the situation is favorable for the changes. For example, the process of clay preparation and the firing have incorporated in the last decades technical innovations to make production more efficient. Potters have acquired electric mills, made bigger kilns with better isolation and modified the fuel. This occurred because institutional programs of development have given credits and because potters realized that these technical strategies did increase their production. However, these innovations only simplified the process of manufacture, they did not change it. The sequence of manufacture and the final products have been maintained as in earlier times. Nevertheless, these innovations to make pottery less arduous have motivated younger generations to continue in this profession.

In a long-term perspective, the function of ceramics has also changed. After the conquest ceramic vessels continued being the most important containers for domestic activities. However, this kind of material was notably less used in ritual contexts. In part, this was because pottery censers were clearly identified with pre-Hispanic religious practices, and were therefore suppressed. Also the Spaniards introduced in the early colonial period containers of other materials, such as metal objects, and other forms for manifesting devotion, such as candles, that became very popular. Due to the reduction of ceramics in ritual activities the function of decoration was also modified. Vessels with pictographic decoration, in which short messages associated to the context in which they were used were depicted, were no longer made by the end of the early colonial period. Thus, the tradition of ceramics as media of literacy disappeared. Vessels continued to be decorated in the late colonial period although motifs became sim- 
pler and less meaningful. At present, in the case of ceramics for domestic uses, decoration is not an important part of the production process; it is simple, hastily done and does not have special meanings for potters or consumers.

The change in the function of ceramics is particularly evident in the case of artesanías. Some of them are per design for utilitarian purposes but potters produce them for urban or tourist markets in which they have only decorative uses. Other objects are specially created for ornamentation, for example, the imitations and reinterpretations of polychrome archeological pieces made by a potter in Metepec. In this case the use of the vessels has been more evidently separated from preHispanic functions, and also the role of decoration has been modified as the painted motifs do not convey the same meanings as in the past. In most households in Mexico today ceramics are not the most common containers, but rather only one type among a variety of objects of other materials. This is, however, not the rule. In contexts in which the Mesoamerican tradition is more present, ceramic vessels are still an important constituent of the cooking implements. Also censers are again present in religious celebrations, in particular in those in which the Catholic and the Mesoamerican rituals intertwine, such as the ceremonies for the Day of the Dead.

\section{The development of ceramic-making during early colonial times}

The Códice de los Alfareros de Cuauhtitlan is in my opinion a clear illustration of the situation of the native ceramic industry in the first decades after the conquest. This document was presented in 1564 by four potters of Cuauhtitlan to the local colonial authority to claim their rights. It shows that by that time potters of domestic wares in the valley of Mexico had adapted to changing circumstances. That is, they were in contact with the colonial administration, had good knowledge of the colonial legal procedure, and used it to claim their rights. The manuscript illustrates with drawings and a few pictographic conventions the vessels paid and not paid for by the alcalde mayor. This is done in pre-Hispanic style although the illustrations are simple and clearly understandable for those not versed in pictography. The juez de residencia in the town commented on this document with a short text in alphabetic writing in Spanish language that potters made this claim because "son pobres e juraron por dios e por Santa maria e a la 
senal de la cruz que no lo piden de malicia syno por alcancar justicia $^{1 "}$.

This shows that potters were well aware of the importance of indicating that they were good Christians and good persons. William Hanks in his recent study of colonial Maya culture convincingly argues that the colonizing process in Yucatán was guided by the logic of reducción, a total project of pacification, conversion and ordering of the indigenous culture that was manifested in the transformation of space, conduct and language. He explains that a main product of reducción were the indios reducidos who acted in accordance with policía cristiana 'Christian civility' (Hanks 2010:xiv-xv). This same process seems to be reflected in the codex of Cuauhtitlan. The document gives the impression that potters clearly recognized the value of showing acceptance of the new Christian habits. The manuscript also mentions that the potters were poor, a general condition of potters of domestic wares at present, and apparently also in the colonial past, but it seems it was important to mention it, as poverty was also part of the Christian values transmitted by the first religious orders in central Mexico. The document was sent to the defendant alcalde mayor and the juez de residencia comments in his answer that he said: "lo es ny es que no le mandado nynguna jarro que no este pagado y que se ... [?] en [...] porque ello [...] piden mas de lo que mercen y en lo [...] dicho aranzel les tiene presentado y satisfecha e sy lo dixe [?] e los di ... [?] 2" (Códice de los Alfareros de Cuauhtitlan).

That is, the alcalde major negates the accusation, and insists that the potters have not paid him the corresponding taxes. This is the only written information in the document (excepting several explanatory glosses for the drawings), so we do not know how this case finished. However, very probably the potters had little chance of success as the word of colonial authorities, even local ones, had more weight, and as can be implied from the text, taxes were an important tool of control and manipulation. The fact that the alcalde mayor of a large altepetl in

\footnotetext{
1 They are poor and swore in front of God, Saint Mary and the Holy Cross that they ask that not because of malice, but because they want to reach justice (Códice de los Alfareros de Cuauhtitlan, my translation).

${ }^{2}$ It was not sent to him any pot that was not paid and that ... [?] in [...] because $[\ldots]$ they want more than they deserve and in ... [...] such tax was presented and resolved and I told them [?] and I gave it them ... [?] (Códice de los Alfareros de Cuauhtitlan). This is the third block of text transcribed by Rosanna Woensdregt. Barlow (1951) only reproduced the last line of this text, but it coincides with the new transcription.
} 
the valley of Mexico requested Red Wares confirms the wide acceptance and distribution of this kind of vessel evidenced in the archeological record. It also shows that local colonial authorities used Red Wares with typical pre-Hispanic shapes, like the molcaxetes illustrated in the document, as well as vessels with shapes related to the Spanish tradition such as alcarrazas, tinajas or cups.

The document also exemplifies the situation of the native ceramic tradition. The vessels represented are Red Wares that had their origins in pre-Hispanic culture. However, the shapes clearly show the interaction of indigenous and Spanish ceramic culture. A few shapes have direct pre-Hispanic antecedents such as the vessels named in the text molcaxetes para cacaos, though the majority show formal attributes of Spanish origin that became very popular in the early colonial period, such as ring bases and cover lids. Also some vessels show the creativity of potters who produced new vessels with ideas taken from the new colonial world, such as those objects named in the text vasijas como negritos, or the vessels with appendages representing Spanish faces. The vessels show a lot of innovation and intertwinement of native and Spanish ideas; however, the study of archeological remains of these kinds of wares indicates that this exchange was somewhat superficial. Ceramics incorporated new formal elements, but the method of forming vessels remained as in pre-Hispanic times.

The text or the brief alphabetic notes explaining the illustrations do not associate the vessels or the pottery of Cuauhtitlan with the indigenous world. Neither the potters nor the vessels are qualified as indigenous. Although the texts are brief and likely omitted a lot of information, the lack of association of the Red Wares of Cuauhtitlan with the indigenous society might suggest that this kind of ceramics and the potters of that town were not unambiguously identified as indigenous. That is, the colonial society in the valley of Mexico, at least in large towns such as Cuauhtitlan, was at that time no longer polarized as indigenous $v s$. Spanish people but a variety of social groups had developed in-between. In particular Red Wares might not have been seen as indigenous wares directly connected with the pre-colonial past, but rather as flourishing colonial ceramics, likely separate of the Spanish tradition, although not part of the past.

The developments of indigenous ceramics after the conquest should not be hastily labeled as decline. Although affected by the Spanish ceramic tradition, Mesoamerican potters reshaped their own notions about pottery and manipulated them as a means to attain their own 
ends. Thus, they manufactured vessels according to the preferences of the new colonial society. For example, the typical Aztec Black-onOrange wares incorporated decorative motifs that were common in all forms of colonial material culture, such as flowers, birds and patterns of leaves. They also elaborated Red Wares with typical Spanish formal attributes, like ring bases and lids, that were apparently very popular at that time. They also produced lead glazed wares as this kind of decoration became the favorite colonial innovation of this industry. However, the methods and goals of the potters were indigenous rather than Spanish. They continued producing with the same process of manufacture the whole repertoire of vessels for the indigenous quotidian life. They also produced a few vessels clearly originated in the Spanish tradition, like the candle holders, because these artifacts were widely adopted in colonial society.

Native ceramic-making in early colonial times corresponded with the general situation of indigenous culture at that time. Lockhart (1992:429) explains that in central Mexico Spanish elements pervaded every aspect of Nahua life, but with limitations, often as discrete additions within a relatively unchanged native framework. Indigenous ceramics show a similar process. Even typical and highly standardized Aztec wares, like the Black-on-Orange vessels, incorporated elements of the Spanish world, in particular decorative motifs. Other indigenous ceramics adopted and reinterpreted more Spanish elements in vessel shapes, morphological details and decorations. However, the indigenous framework for ceramic-making was preserved. Vessels continued to be conceptualized in the same way as in the past, and were made with the same process of manufacture and organization of production, and knowledge was transmitted using the same mechanisms as in the past.

The pre-Hispanic ceramic categorization was modified, however. The codex of Cuauhtitlan evidences that a majority of vessels received Spanish names (although it is not clear if this was only in contexts of contact with colonial authorities). In his tenth book Sahagún (1961, $\mathrm{X}: 83$ ) shows that the indigenous taxonomy of vessels was simplified in the translation to the Spanish language. For example, he offers eight different Nahuatl terms for bowls, which in the Historia General he concentrates in one term: vaso (see Table 1) (Sahagún 1992, X:571). In addition, the nomenclature for vessel dimensions changed after the conquest. At present in some pottery towns of central Mexico potters categorize the various sizes of a vessel shape according to pre-His- 
panic, colonial and modern conceptions. For example, in Amozoc some sizes of cazuelas are named according to their price in reales, others according to spans of a hand, and still others are called de a tlaco. Although it is not clear when these terms were introduced into the nomenclature, this shows that after the conquest the ceramic categorization began to be modified, and in that process it incorporated and mixed various systems.

\section{The development of ceramic-making at present}

The pre-Hispanic ceramic tradition has persisted until the present time. Today it is known as 'traditional' or 'typical' pottery. In central Mexico towns specialized in the manufacture of this kind of ceramics are often associated with the contemporary indigenous culture, or have direct indigenous antecedents, although this is not the rule. Still, we can categorize this form of material culture as 'indigenous-style' because it has preserved the central elements of the pre-Hispanic ceramic culture, and is related to other aspects of the indigenous world such as food habits and the close link between family, means of subsistence and place of production. Although in the last four decades pottery towns in central Mexico have been involved in the enormous social and economic changes in Mexican society, potters continue to use the same process of manufacture as in the past, and the family workshop continues to be the unit of production. The situation of the pottery towns in this region is particularly interesting. Most of them are close to large metropolises and have incorporated many elements of urban culture. They are also placed next to important communication routes and intermediaries have greatly increased the scale of distribution of their products. Due to their central location, the ceramic industry of several of these towns has received an important boost in the last decades. Although urban culture is widely extended in central Mexico, indigenous domestic habits are still preserved in some rural and urban contexts. Thus, cooking implements such as comales, ollas and cazuelas are still requested. Also 'traditional' ceramics are in demand in urban contexts for serving Mexican food or for ornamentation.

In these pottery towns many young people now go to work or to study in the cities or migrate to the United States. Despite the intense contact with other cultural frameworks, pottery has conserved the 
core elements of the pre-Hispanic ceramic culture. In my opinion, the main reason for this is that the family workshop continues to be the unit of production. The family structure, even when some members go to work or study in other places, has promoted that the organization and schedule of production has been maintained as in the past, and that the transmission of knowledge has not been interrupted. In those pottery towns ceramic-making is very conservative in the method of forming but innovative in decoration and morphology. Potters are quite open to new decorations and shapes if customers require them. These two different forces result, on the one side, from the fact that this industry is still embedded in the family and is a strong source of cultural stability, and on the other, from the fact that young potters have to adapt to the current needs of the market if they want to earn a living with this craft. In these towns intermediaries are often important motors of innovations, as they are aware of the preferences of customers and new trends outside of the town. However, they often exploit the potters. They pay them very low prices for their products so that potters have to ask them for credits to continue with the production, and are not able to create the capital to improve their facilities or resolve other problems of life. This has also had negative consequences for the ceramic tradition, as potters have to save as much as possible in the production, and therefore they often produce simple or rough vessels without decoration or use plastic trash as fuel.

For several decades institutional programs of development have tried to improve the social and economic situation of Mexican potters. They have promoted the creation of cooperatives in order to restrict the influence of intermediaries and stimulate potters to commercialize their products. They have given credits to acquire electric mills or better kilns, and they have offered courses in which new techniques of manufacture and methods of decoration are taught. Although the main lines of action would be adequate to solve the central problems of potters, many of these programs have failed because they have responded to political agendas and have therefore lacked continuity. Also the projects have not been adapted to the particular situation of the pottery towns. For example, the regulations of cooperatives have often not been in accordance with the social organization of a town, or the gas kilns offered have not corresponded to the volume of production and the size of the workshops. Regardless of this, in the last forty years programs of development have been important sources of change. In some pottery towns today, as is the case of San Miguel 
Tenextatiloyan, all potters use electric mills, electric mixers and efficient kilns. Also some potters are experimenting with new vessel shapes and forms of decoration learnt on the capacitating courses. Potters are also organized into cooperatives. Until now all these innovations have contributed to make production more efficient and less arduous and have improved slightly the social and economic situation of potters. Nevertheless, the process of manufacture, and in particular the method of forming, still conserves many aspects of the ancient ceramic tradition.

\section{Ceramics and cultural continuity}

Knowledge and experience associated with indigenous ceramic-making continued to be transmitted after the conquest. The family workshop was not only the place where this traditional craft was done, but also the mechanism for conveying the understanding of pottery across generations. Lockhart (1992) has convincingly shown that during the early colonial period there were few changes in the organization of the indigenous communities of central Mexico. The persistence of the communal framework in the first post-conquest century certainly promoted the maintenance of the family workshop. Although colonial documentary sources provide scant information about this form of industry, the present-day predominance of family workshops in the manufacture of traditional crafts suggests that it has been the central unit of production since pre-Hispanic times.

Today the pottery workshop in general involves two family generations. This is also the rule in the pottery towns of central Mexico which intensively produce lead glazed vessels. This guarantees that knowledge is transmitted in the family without interruption. Usually all members of the family-elders, young people, children-are involved, although many of them only in an informal way. Habitually potters instruct some of their children or nephews in the method of forming vessels more in depth. These are the children who do not go to work outside the town or do not study and therefore remain helping in the workshop. Young potters learn the required motor skills and experience by frequent repetition, so that these are soon internalized and become habits. Thus, this knowledge is implicitly transmitted by means of body performance across generations in the context of the family. The knowledge required to make vessels in a particular way 
continues to be transmitted because this is the method that potters learnt from their parents, but also because the particular kind of vessels made with this method are still preferred by potters and requested by customers.

Ceramic-making is only one example of the great variety of knowledge that was transmitted by body performance, in an implicit way, across generations in the pre-Hispanic past. A large part of ancient knowledge was composed of this kind of understanding, for example, agricultural practices, food habits, hunting and fishing or the manufacture of other crafts. In the same way as the ceramic technology, these aspects of life were embodied in actions and transmitted in the family without them being clearly aware of it. Their persistence over a long span of time gave cultural continuity to Mesoamerica. This kind of information complemented the knowledge conveyed by means of explicit mechanisms of memory, like books, monuments and ritual practices. They commemorated past events and in that way ancient knowledge and experience was deliberately transmitted across time and made part of the present time. In the words of Assmann and Czaplicka (1995:130-132), these media maintained the knowledge from which the Mesoamerican culture constructed its living identity.

However, after the conquest these declarative media of remembering were suppressed. It is widely documented that Christian monks burned native books and prohibited public ceremonies of the ancient religion. Parts of the knowledge linked to these media, however, did not disappear; they became confined to oral literature and merged with new understandings and experiences. In my opinion, media of implicit memory acquired a new importance. That is, mechanical, repetitive and ritualized activities became the main media to transmit knowledge. It is possible that these activities, and their material manifestations, served to recall the pre-Hispanic past, and in that way helped to construct the self-image of the indigenous society after the conquest. This might be the case of agricultural practices and of native crafts, such as ceramic-making. The mechanism for transmitting knowledge was the performance of sequences of actions, very internalized, in the context of the family.

In the case of pottery, the early introduction of the Spanish ceramic tradition to Mexico City, which used other methods of manufacture and firing, vessel shapes and decoration might provoke that at the beginning native ceramic-making was seen as distinctive of the indigenous culture, clearly contrasting to the Spanish tradition. At that 
time it was recognized that a basic difference between the two traditions was the method of forming. This can be observed in one of the few documentary references to indigenous ceramic-making in the early colonial period. An early manuscript mentioned before in this book, the document sent by Viceroy Lorenzo Suárez de Peralta in 1583 to the alcalde mayor of Michoacán shows that colonial authorities recognized ceramics made with molds as distinctive of the indigenous world, and by the way, they characterized them as deficient and fraudulent. In the text the viceroy makes a distinction between olleros and oficiales para hacer platos y escudillas. It seems that the first made indigenous-style vessels while the latter made Spanish-style vessels. This division seems also related to the techniques used, so what he calls platos mal hechos con fraude y engaño were likely vessels made with the indigenous methods of forming, that is, with molds. Thus, it seems that the method of forming - the use of molds or wheelbecame emblematic of both ceramic traditions. These two methods of forming were associated with different ceramic complexes as manufacturing marks on archeological ceramic remains suggest. Vessels made by mold had shapes, surface finishing and decoration originated in the pre-Hispanic ceramic tradition. In the same way, vessels made by wheel had shapes, surface finishing and decoration associated with the Spanish ceramic tradition. Lead glazed wares clearly exemplify this separation. Glazed wares made with molds had shapes that were part of the Mesoamerican repertoire while glazed wares made by wheel had Spanish-style shapes. The separation of these two ceramic complexes on the basis of their forming method may imply that the two groups of vessels were made in different workshops.

The 1583 document of the viceroy Suárez de Peralta suggests that by that time there were institutional efforts to separate the two ceramic traditions. He wrote that there were oficiales in this industry and they made platos and escudillas, while at the same time there were indios olleros que no son ni han sido ni pueden ser oficiales de dicho oficio ni lo saben hacer dichos platos mal hechos $y$ de donde se sigue fraude $y$ engaño. This implies that there was a kind of guild or organization for potters who made pottery in the correct manner (with the wheel), which instructed potters outside the family and conferred authorization to practice this activity. Such institution, apparently antecedent of the pottery guild officially founded in Puebla in 1653, separated even more the indigenous-style ceramic tradition from the Spanishstyle ceramic tradition. Not only were the products different but also 
the form of knowledge transmission varied. That is, it seems that the first one was centered on family workshops while the second was centered on non-family workshops with apprentices, officials and masters. Although non-family workshops had rules dictated by the guild statutes, the broadcasting of information to younger generations was less personalized and not attached to core values of the society, such as respect to the elders, and therefore the dynamics of change were different.

It is possible that after the early colonial period vessels made by mold were no longer associated with the indigenous pre-Hispanic culture. Vessels made by mold and vessels made by wheel still constituted two separate complexes with different methods of firing, shapes, finishing and decorations. However, potters specialized in vessels made by mold incorporated a growing number of new shapes and decorations so that the visual connections of these objects with the pre-conquest past were reduced. At present pottery made by mold is still separated from pottery made by wheel. The first group is considered 'traditional' or 'typical' pottery, and in that way it is still connected by some potters and consumers with ancient ceramic traditions. However, this industry is today not a commemorative element of indigenous culture. It does not deliberately mark ideas to be remembered. Rather, it is part of the ancient knowledge and experiences that have been implicitly transmitted in the family till the present time. It is one of the elements that have made possible the continuity of Mesoamerican culture in the twenty-first century.

\section{The role of material culture in the process of colonization}

Material culture clearly reflects actions of people and social processes. For example, indigenous potters after the conquest continued working as in the past, with the same conceptualization about their craft, but they were impressed by the new visual culture introduced by the colonizers. This had echoes in their ceramics, and for this reason, we find in early colonial contexts vessels made in the Late Aztec style with new decorative motifs such as leaves, flowers and birds, and new supports in the form of pig hoofs and lion claws. However, material culture is not only a reflection of social actions but also provokes social actions. That is, it also has agency. In the first years after the conquest indigenous-style ceramics represented the pre-Hispanic world and for 
this reason they related their makers and users with the indigenous culture and accordingly created particular social relations. In the same way, Spanish-style ceramics represented the Spanish world, or the group of social ideas that Kathleen Deagan (2001:186) in the Caribbean colonial context has called hispanidad, and for this reason, they related their makers and users with the Spanish culture. In an early account from 1529 sent by Alonso Figueroa to Charles V. it is stated that Spanish wares were necessary to maintain the Spanish way of life.

However, several decades after the conquest it seems that the bipolar association between Spanish ceramics and the Spanish world and between indigenous ceramics and the indigenous world was no longer existent, and for this reason, the actions that ceramics provoked were ambiguous. The several indigenous-style ceramics of the early colonial period were connected in different ways to the ancient ceramic tradition. For example, the Black-on-Orange wares were made as in the past and look as in the past, and therefore we can suppose that people connected them to the pre-Hispanic past. Red Wares, in contrast, had their origins in pre-Hispanic times and maintained the ancient methods of manufacture. However, they incorporated several morphological details and decorations of the Spanish culture as well as new elements not present before in both the indigenous and Spanish ceramics. Thus, they likely provoked ambiguous responses. Probably, according to the context, these red vessels could bring to mind the pre-Hispanic past and associate their users with the indigenous culture, or they could just evoke the colonial present. Thus, they were probably not related to the indigenous and pre-colonial past as we today suppose. The codex of Cuauhtitlan and other scattered documentary references did not relate them to the indigenous society. Juan Suárez de Peralta even mentions that they were used by new colonial nobility (1990 [1589]:185). For example, he says that they were used as serving ware in a dinner organized by Alonso de Avila of Cuauhtitlan for the wife of the Marqués del Valle.

Very probably Red Wares continued and flourished in early colonial years because they promoted a variety of social responses, and for this reason, were appropriate for a variety of contexts. Lead glazed wares were even more ambiguous. Some vessels had Spanish-style shapes and were imported from Seville, others had Spanish-style shapes but were made in Mexico City in Spanish-style workshops, others had Spanish-style shapes but were made in indigenous-style workshops with pre-Hispanic manufacturing methods, and others 
had indigenous-style shapes and were made in indigenous-style workshops. Thus, they likely motivated in their users different associations, and also different social relations. All this shows that early colonial ceramics cannot be simply divided into two groups, indigenous $v s$. Spanish, as we do today. Thus, early colonial ceramics reflected the existent social relations and at the same time created them, but these relations were more varied and complex than the simple opposition between indigenous (colonized) and Spaniards (colonizers).

In my opinion quotidian material culture, like domestic ceramics, did not play an important role in the process of colonization. Probably only in the first years after the conquest ceramics categorized people and provoked particular social relations. It might be for this reason that Aztec Black-on-Orange wares and the polychrome vessels disappeared and Majolica wares extended in urban contexts. However, after some years potters and vessel users adapted to the new circumstances, and therefore there were produced ceramics in accordance to the new colonial reality. It seems that access to the variety of ceramics available on the market was not determined by the social situation of the consumers but by their economic position. For this reason, we find Red Wares in affluent houses of La Traza in Mexico City, as well as in domestic areas of the indigenous city of Cholula, or we frequently find Majolica wares in contexts associated with colonial authorities in the city but also a few examples in rural and indigenous locations, like the countryside of Otumba.

\section{Reactions of Mesoamerican potters to the colonization}

Indigenous potters reacted to the new post-conquest circumstances. They continued producing vessels for the indigenous market, with the same shapes as before. They decorated these objects in the same way as in the past but also incorporated new motifs inspired by the colonial world. They also began to make vessels with new formal elements and to create new vessel shapes to meet the colonial needs. For example, they made candle holders or Red Wares with shapes of Spanish origin, such as plates, cups or tee canes. They also adopted the lead glaze technique because it was an appealing novelty and became very popular. That is, they adopted and reinterpreted several visual elements of Spanish ceramic culture, and developed new elements out of 
their pre-Hispanic tradition. However, all these innovations were done at the surface of their ceramic tradition. Potters wanted to supply the new market but there was no reason to modify the organization and process of production, because the colonial regime did not interfere with the framework of this industry.

We cannot qualify the reactions of the colonial potters as subversive. Ceramic remains and the scarce documentary references do not suggest that potters used their pots to actively oppose the new colonial regime, either in an explicit or an implicit manner. This form of material culture was not at the center of the project of colonization, and for this reason, in my opinion, it was not openly involved in the cultural struggle of that time. Without diminishing the dramatic impact of the conquest, we observe that the main distinctive of the potters of the early colonial period is that they were adapting their craft to the new situation. They adopted several elements of the Spanish ceramic tradition, and rejected others, but we cannot assume that this cultural transfer was politically or ideologically charged as we might believe today.

The fact that this work has concentrated on indigenous-style ceramics may give the impression that indigenous potters did not manufacture Spanish-style ceramics, like Majolica wares. Flora Kaplan (1994:7) mentions that a document from the cathedral archives of Puebla states that in 1681 an indigenous potter, an oficial de lo blanco (a skilled potter of white ware, that is Majolica), was married. However, in the 1653 potters' guild regulations of Puebla it is mentioned that: ... que no se pueda admitir examen de dicho oficio, a ningún negro, ni mulato, ni otra persona de color turbado, por lo que importa que lo sean de toda satisfacción y confianza ... (Ordenanzas de Loceros de Puebla, in Novelo 2007:100). We do not know how extended the presence of indigenous potters in Spanish-style workshops was, or if the situation during the late colonial period was different to early times. However, ceramic remains from that time suggest that potters were not avoiding the Spanish ceramic tradition. Red Wares incorporated forms of Spanish origin, molcajetes were glazed and Black-on-Orange wares included supports in the form of lion claws. However, it seems that they did not perceive the Spanish ceramic technology as more advanced. Indigenous potters maintained their process of manufacture although they were certainly aware of the methods used by Spanish-style potters. Lead glazing, for example, was imitated very early. 
During the process of colonization potters continued to transmit the ancient ceramic knowledge to younger generations. In that way they actively contributed to the preservation of Mesoamerican culture. Today the social and material effects of the Spanish colonization are still present in many aspects of life in central Mexico. In the case of ceramic-making, some colonial elements are still well recognizable, for example, decoration with lead glaze is widely extended. However potters and users of the vessels do not see it as Spanish or colonial attribute, but rather as a typical characteristic of the contemporary traditional pottery.

\section{The prospects for ceramic-making}

The Mesoamerican ceramic culture has a future. The pottery towns of central Mexico specialized in lead glazed wares for domestic uses are now flourishing, and we do not see signs that this will change in the near future. The market for this kind of ceramics is alive. Although the production of some artifacts for Mesoamerican cooking practices, like comales, has been reduced in the last decades, the production of other objects, like cazuelas or arroceras, has increased. Potters now make more vessels for the urban market, like ollas for piñatas or flower pots. Thanks to new roads and highways, the pottery towns are accessible, and the products can be distributed to many regions in the country. Potters, or their intermediaries, are aware of the preferences of the market and the new developments and react to them. And what is more important, knowledge continues to be transmitted to younger generations. Potters are now implementing technical innovations to make this industry more efficient and less arduous. Programs of development have had an important role here. Although these projects have often failed, we have to recognize that their lines of action have been directed to improve the situation of potters and at the same time to conserve the core elements of the traditional pottery. For this reason, they have insisted on the creation of cooperatives to avoid intermediaries, but have not interfered with the organization of the family workshop or with the process of manufacture. In the past some programs tried to introduce the wheel, but this was not successful and is no longer promoted. Even with these technical innovations, potters have preserved their method of forming. The production continues to be organized in family workshops. For this reason, we can prognosti- 
cate that knowledge will be conveyed to new generations, and the process of cultural continuity will be maintained, at least in the near future.

The production of artesanías has also opened new possibilities for potters. In this field there is much more diversity than in the manufacture of domestic wares. Some potters have specialized in vessels for domestic purposes that are used as decoration in urban contexts. Others are making vessels or figures in new styles considered by urban consumers as 'traditional' and still others are reproducing archeological objects. All these objects manifest the creativity of potters and are constantly changing; nevertheless, they are made according to ancient methods of manufacture in family workshops. The production of artesanías is in general terms more profitable for potters although commercialization is more difficult, as there are fewer channels or they depend on state programs of development.

Although ceramic-making has prospects in central Mexico, this unfortunately does not mean that the social and economic situation of potters will be better. Many of the young potters, especially in the towns located on the periphery of big cities, are those who do not want to study or do not have another work alternative. Intermediaries are still widely present, and are still contributing to increase the poverty of many potters. Also some institutional projects have made potters dependant on their help. Limited access to fuel has become the main concern of this industry. In addition, there are several towns in which ceramic-making has been interrupted, and now only older potters sporadically make vessels. In large part, the reason for this is that these places are not located close to important communication roads, and young people, for several reasons, do not continue with this profession. Nevertheless, none of this has discouraged most potters from continuing to look to the future with positive eyes.

This is not a characteristic exclusive of the pottery craft. Mexico is a young nation; a large part of the population is still under twenty-five years old. The colonial past and the recurrent crisis of the last half century have provoked people to continuously expect better times. In addition, the enormous social and economic transformations of the last decades have made people used to changes, and to see in changes opportunities. Most potters, like the majority of Mexicans, are conscious that they have to react to changing circumstances. For this reason, Mesoamerican ceramic-making has a future. 